\title{
Socio-Economic Behind TOD in Jakarta
}

\author{
Riza Harmain, Hayati Sari Hasibuan*, Ahyahudin Sodri \\ School of Environmental Science, Universitas Indonesia, Jakarta, Indonesia
}

\begin{abstract}
TOD is a popular urban development concept implemented by many countries around the world, especially in Indonesia. This concept is also an exciting thing to study in various countries, but that does not happen in Indonesia. Research on the socio-economic TOD is still relatively less desirable than another focus. Therefore this research exists to provide new things in research on TOD in Indonesia. This research aims to identify the socio-economic condition based on three indicators, namely mobility movement, economic activity, and life quality. This research uses descriptive methods based on the response from 100 passengers from two TOD areas, namely Dukuh Atas and Lebak Bulus. The results show that movement mobility indicates a stable condition due to the short travel and transit time felt by the community. The economic activity occurs due to the commercial facilities around the TOD area. The life quality change appears caused by the benefits took by the community. This research shows that TOD in Indonesia creates socio-economic phenomena and has to further developed. This research can also be an incentive for academics to conduct similar research in the future.
\end{abstract}

\section{Background}

TOD area is a high density urban developing area driving by public transportation and mixlanduse that capable of attracting the community to do their activity [1]. The TOD area emerges as a part of urban infrastructure giving benefits and becomes one of the means to create sustainable development [2]. Several benefits provided by TOD are reducing traffic jams and air pollutions, raising community interest in using public transportations rather than the private car, and increasing economic activity around the area [3-6]. Benefits provided by the TOD area cause this urban concept to become a popular concept around urban development planning.

This popular concept has implemented in many countries around the world. The implementation of the TOD concept in India leads to high demand for housing around the transit point [7]. In other countries like the USA, the implementation of the TOD concept reducing $30 \%$ use of the private car and raising the value of property business $[8,9]$. The implementation of the TOD concept is successfully to recreate the green space around the urban area [10]. However, the essential benefits arising from the TOD cannot be separated from the critical success factors

The TOD concept has several keys to success in the implementation process, namely,

\footnotetext{
*Corresponding author: hayati.hasibuan@ui.ac.id
} 
travel behavior, built environment, economic condition, and social diversity [11]. This research tries to focus on travel behavior, economic condition, and social diversity aspects. Several kinds of research conducted focusing on those socio-economic aspects in the last few years. The research about travel behavior in Toronto, Canada, proved that the TOD increasing the travel by walking due to the excellent walkability around the TOD $[12,13]$. The research about economic conditions in the TOD around New Jersey, USA, proved that the property value around the TOD area is increase due to the service coverage of transit point [14].

Indonesia has implemented the TOD concept in several urban areas, especially in Jakarta. Nevertheless, research on the socio-economic of the TOD is still relatively less desirable. Therefore, this research is trying to cover up these deficiencies. This research objective is to identify the socio-economic condition that appears due to the travel and transit activities around the TOD. The socio-economic aspects discussed in this research focusing on mobility movement, economic activity, and life quality. The aspect chose based on the research conducted, which focuses on mobility movement, economic activity, and life quality, consists of economic benefits, social benefits, and environmental benefits [1, 15-18].

\section{Research Methods}

This research is quantitative. This research consists of three variables, namely mobility movement, economic activity, and life quality. Mobility movement analyzed using trend and projection analysis. Economic activity and life quality are analyzed using descriptive methods. This research conducted from January to December 2019. The sampling technique used in this research is purposive sampling considering Jakarta's MRT passenger assumed as people who travel and transit in the TOD area. The sampling conducted in this research expected to obtain specific information related to the research variables. This research is using 100 respondents who travel and transit in the TOD areas. Each response from respondents used to justify every aspect of variables in this research, then used as the materials in the analysis process.

The trend analysis method carried out by creating the fluctuation graph of Jakarta's MRT monthly passengers from April to September 2019. Subsequently, the projection analysis process conducted by extrapolating the number of Jakarta's MRT monthly passengers for the following months. Trend analysis also carried out to determine matters relating to passengers such as the intensity of passenger movement, origin and destination of transit locations, transportation mode preferences, types of transportation modes used, reasons for using modes of transportation, costs incurred, economic benefits, social benefits, and environmental benefits. The descriptive analysis used to explain each aspect of socio-economic conditions in order to sharpen the results of the analysis.

\section{Results and Discussion}

\subsection{The Overview of TOD in Jakarta}

This research conducted in two TOD areas of Jakarta, namely Dukuh Atas and Lebak Bulus. Geographically, the TOD of Dukuh Atas located at $6^{\circ} 12^{\prime} 05^{\prime \prime} \mathrm{S}$ and $106^{\circ} 49^{\prime} 22^{\prime \prime} \mathrm{E}$, while the TOD of Lebak Bulus located at $6^{\circ} 17^{\prime} 21^{\prime \prime} \mathrm{S}$ and $106^{\circ} 46^{\prime} 29^{\prime \prime}$ E. The TOD of Dukuh Atas administratively located in Central Jakarta, while the TOD of Lebak Bulus administratively located in South Jakarta. Dukuh Atas and Lebak Bulus are two of four TOD areas in Jakarta developing related to the Jakarta's MRT route phase one. Dukuh Atas planned to become an international hub consist of three kinds of public transportation transit points, namely MRT, BRT, and electric railway train. On the other hand, Lebak Bulus planned to 
become a terminus gate of the urban community movement.

The TOD of Dukuh Atas regionally consists of three sub-districts, namely Tanah Abang, Setia Budi, and Menteng. Then, the TOD of Lebak Bulus regionally consists of two subdistricts, namely Cilandak and Kebayoran Lama. The TOD of Dukuh Atas functionally dominated by trade, business, and services sectors, while the TOD of Lebak Bulus functionally dominated by housing. The TOD of Dukuh Atas demographically denser than the TOD of Lebak Bulus. It caused by the amount of travel and movement in the TOD Dukuh Atas bigger that the TOD of Lebak Bulus. Fig. 1 shows a map of the research location.

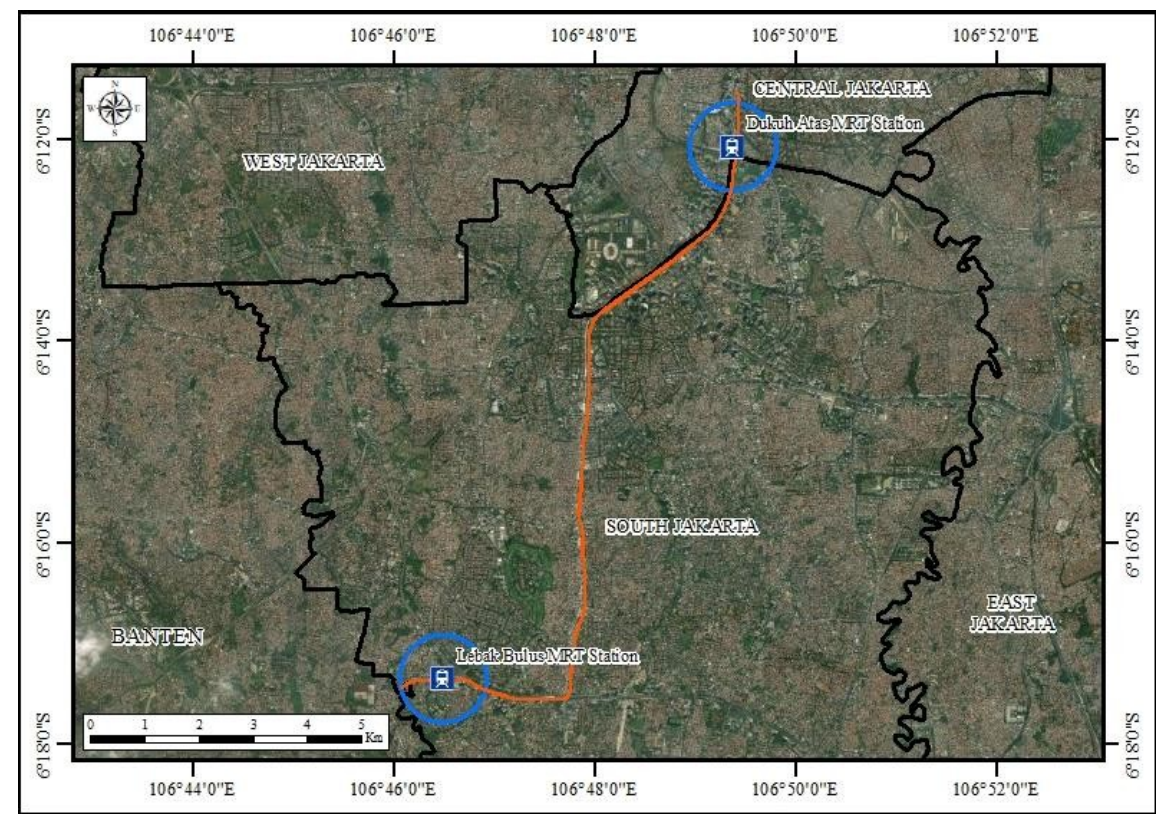

Fig. 1. Research Location Map

\subsection{Movement Mobility}

The movement mobility on the TOD of Dukuh Atas and Lebak Bulus analyzed from the total number of Jakarta's MRT monthly passengers. Based on the number, the highest number of monthly passengers was in July, which reached 2,888,126 persons, and the lowest number of passengers was in September, which reached 2,138,571 persons. Overall, the total number of passengers in six months is $14,959,332$ persons. Table 1 shows the total number of Jakarta's MRT monthly passengers from April 2019 to September 2019.

Table 1. Monthly passengers of Jakarta's MRT

\begin{tabular}{|c|c|c|}
\hline No & Month & Passengers (Person) \\
\hline 1 & April & 2.373 .415 \\
\hline 2 & May & 2.253 .559 \\
\hline 3 & June & 2.448 .856 \\
\hline 4 & July & 2.888 .126 \\
\hline 5 & August & 2.556 .805 \\
\hline 6 & September & 2.138 .571 \\
\hline
\end{tabular}


Based on the trends of Jakarta MRT passengers, there are fluctuations in the monthly number of passengers. There was a decrease in the number of passengers in May, subsequently an increase in the number of passengers in June and July, then decreasedagain in August and September. It assumed that the fluctuation occurs by the community adaptation of a new kind of transportation mode. The other motive causing the fluctuation is due to the school holiday in June and July. On the other hand, the transportation costs are quite expensive, causing a decrease in August and September. The fluctuation graph showed in Fig 2.

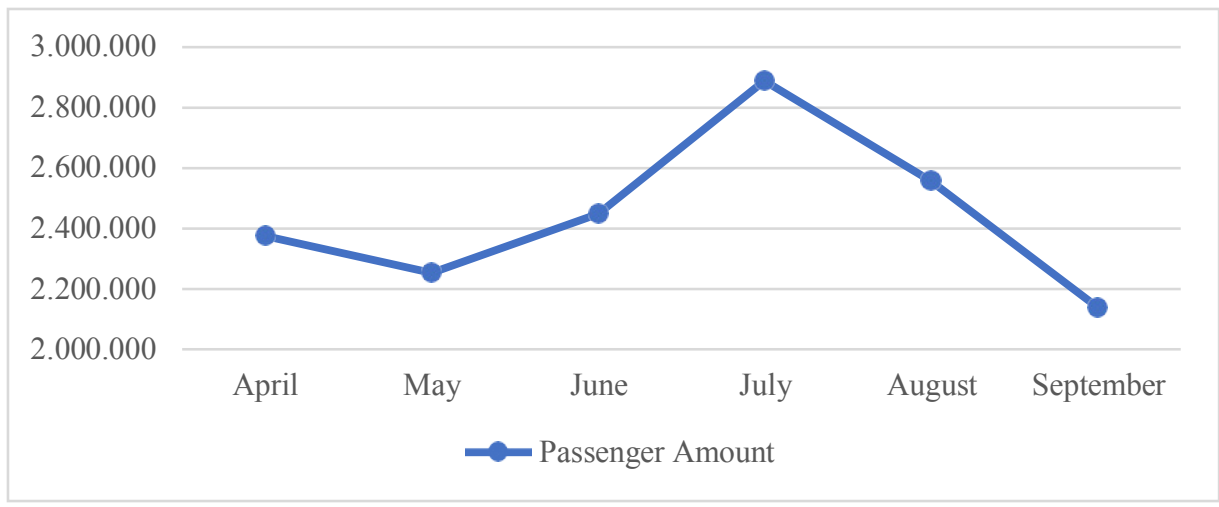

Fig. 2. The trend of Jakarta's MRT passengers in 2019

Based on the fluctuation in the number of Jakarta's MRT passengers, a projection analysis conducted from October to December 2019. The result shows that there was an increase in October and then decreased in November and December. The increase in the number of passengers in October predicted due to a change in transportation mode management policies. Besides, the decrease in the number of passengers in November and December predicted because of the high ticket prices caused by choice change. Table 2 shows the projection results from November to December 2019.

Table 2. Projected number of Jakarta MRT passengers until December 2019

\begin{tabular}{|c|c|c|}
\hline No & Month & Passengers (Person) \\
\hline 1 & April & 2.373 .415 \\
\hline 2 & May & 2.253 .559 \\
\hline 3 & June & 2.448 .856 \\
\hline 4 & July & 2.888 .126 \\
\hline 5 & August & 2.556 .805 \\
\hline 6 & September & 2.138 .571 \\
\hline 7 & October & 2.460 .701 \\
\hline 8 & November & 2.435 .123 \\
\hline 9 & December & 2.311 .113 \\
\hline
\end{tabular}

Movement mobility also analyzed from the view of passenger movement intensity. The survey shows that there is a variation of movement intensity every day. On the TOD of Dukuh Atas and Lebak Bulus, the highest intensity occurs in people who move in five days a week. It caused due to the movement conduct is for work. The intensity of every passenger shows in Table 3. 
Table 3. Movement intensity in the TOD of Jakarta

\begin{tabular}{|c|c|c|c|c|c|c|c|c|}
\hline \multirow{2}{*}{ No } & \multirow{2}{*}{ TOD Area } & \multicolumn{5}{|c|}{ Intensity (Day/Week) } & \multirow{2}{*}{ Amount } \\
\cline { 3 - 8 } & & 1 & 2 & 3 & 4 & 5 & 6 & \\
\hline 1 & Dukuh Atas & 5 & 7 & 14 & 2 & 70 & 2 & 100 \\
\hline 2 & Lebak Bulus & 3 & 15 & 16 & 4 & 40 & 22 & 100 \\
\hline
\end{tabular}

Movement mobility also analyzed based on the travel scheme observed from the origin and destination of each individual who move and transit in the TOD Dukuh Atas and Lebak Bulus. On the TOD of Dukuh Atas, the most dominant scheme is a move from Dukuh Atas Station to Lebak Bulus Station. While on the TOD of Lebak Bulus, the most dominant scheme is a move from Lebak Bulus Station to Bundaran HI Station. It caused due to the movement scheme that occurs for the work of each individual. On the other hand, geographically, Dukuh Atas station and Bundaran HI Station are located in the SudirmanThamrin Corridor. The travel scheme of people movement showed in Fig. 3.

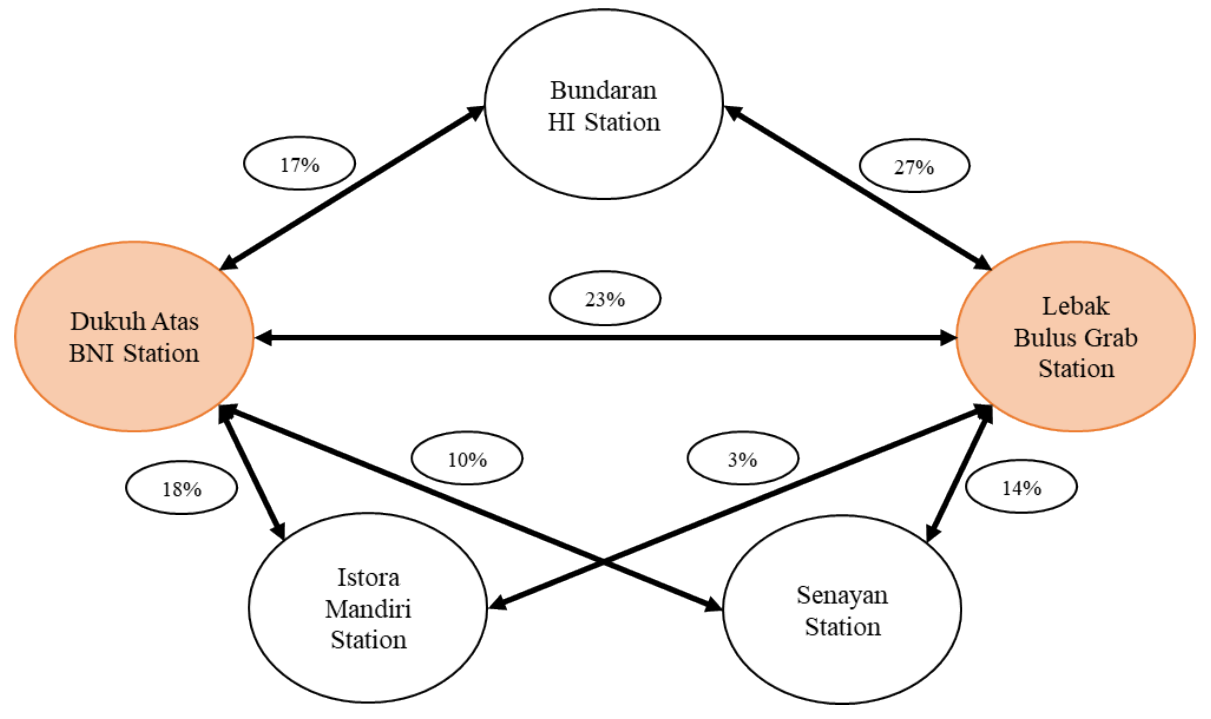

Fig. 3. Movement mobility scheme in the TOD of Dukuh Atas and Lebak Bulus

Movement mobility also analyzed based on the choice preference observed from each individual who move and transit using MRT in the TOD of Dukuh Atas and Lebak Bulus. For both TOD, time efficiency becomes the main reason for people using public transportation. MRT provides a sound management system of train departure schedules, length of transit, and travel speed. For the other reason, such as easy access and comfortable, people still think of it as something less important. On the other hand, using public transportation for reducing jams become the lowest reason, although it is an environmental reason. The choice preference for using MRT showed in Table 4.

Table 4. Choice preferences for using MRT for transit purpose

\begin{tabular}{|c|c|c|c|c|c|c|}
\hline \multirow{2}{*}{ No } & \multirow{2}{*}{ TOD Area } & $\begin{array}{c}\text { Easy } \\
\text { Access }\end{array}$ & $\begin{array}{c}\text { Time } \\
\text { Efficiency }\end{array}$ & Comfortable & $\begin{array}{c}\text { Reduce } \\
\text { Jams }\end{array}$ & Total \\
\hline 1 & Dukuh Atas & 18 & 52 & 27 & 3 & 100 \\
\hline 2 & Lebak Bulus & 17 & 66 & 15 & 2 & 100 \\
\hline
\end{tabular}


Besides the choice preference of using MRT, the choice preference of another transportation mode also observed to complete the identification. Based on the TOD of Dukuh Atas, the most dominant combination of other transportation is walking MRT public transportation. It caused the final destination of the passenger is close to the transit point of MRT. So, people can easily reach their destination only by walking. On the other side, people have their residence close to transit points. The mode choice variation in Dukuh Atas showed in Table 5.

Table 5. Mode choice from/to Dukuh Atas Station

\begin{tabular}{|c|l|c|}
\hline No & \multicolumn{1}{|c|}{ Mode Choice Type } & Percentage (\%) \\
\hline 1 & Walking $><$ Public Transportation & 31 \\
\hline 2 & Privat Vehicle $><$ Walking & 14 \\
\hline 3 & Walking $><$ Online Taxi & 15 \\
\hline 4 & Walking $><$ Walking & 10 \\
\hline 5 & Online Taxi $><$ Public Transportation & 16 \\
\hline 6 & Privat Vehicle $><$ Public Transportation & 6 \\
\hline 7 & Online Taxi $><$ Online Taxi & 1 \\
\hline 8 & Public Transportation $><$ Public Transportation & 6 \\
\hline
\end{tabular}

On the other condition, the TOD of Lebak Bulus shows the different mode choices from or to the MRT station. The most dominant mode choice is using an online taxi MRT public transportation. It is similar to what goes on in the TOD of Dukuh Atas, but online taxi considered as the most practical transportation mode from the origin to the transit point. The TOD of Lebak Bulus is the closest transit points to the borderline of Jakarta. So, this point serves the demand for public transportation for users who come from outside Jakarta. The mode choice variation in Lebak Bulus showed in Table 6.

Table 6. Mode choice from/to Lebak Bulus Station

\begin{tabular}{|c|l|c|}
\hline No & \multicolumn{1}{|c|}{ Mode Choice Type } & Percentage (\%) \\
\hline 1 & Walking $><$ Public Transportation & 11 \\
\hline 2 & Privat Vehicle $><$ Walking & 16 \\
\hline 3 & Walking $><$ Online Taxi & 3 \\
\hline 4 & Walking $><$ Walking & 15 \\
\hline 5 & Online Taxi $><$ Public Transportation & 47 \\
\hline 6 & Privat Vehicle $><$ Public Transportation & 3 \\
\hline 7 & Online Taxi $><$ Online Taxi & 3 \\
\hline 8 & Public Transportation $><$ Public Transportation & 1 \\
\hline 9 & Privat Vehicle $><$ Online Taxi & \\
\hline
\end{tabular}

\subsection{Economic Activity}

Economic activity in the TOD in Jakarta explained based on several aspects, one of them is travel cost. It observed based on the total cost spent in the term of doing activity and transit in the TOD area. According to the survey, the travel cost spent by people to travel and transit in the TOD of Dukuh Atas is between IDR 4.000 and IDR 100.000. Table 7 shows the travel cost estimation of each people to travel and transit in the TOD area. 
Table 7. Travel cost of people in transit point of Dukuh Atas

\begin{tabular}{|c|l|c|}
\hline No & \multicolumn{1}{|c|}{ Cost Estimation } & Percentage (\%) \\
\hline 1 & >IDR 10.000 & 21 \\
\hline 2 & IDR 10.000 - IDR 20.000 & 23 \\
\hline 3 & IDR 20.000 - IDR 30.000 & 40 \\
\hline 4 & IDR 30.000 - IDR 40.000 & 4 \\
\hline 5 & <IDR. 40.000 & 2 \\
\hline
\end{tabular}

Based on Table 7, the most dominant travel cost spent by people to travel and transit in the TOD of Dukuh Atas is around IDR 20.000 to IDR 30.000. If the nominal calculated for one round-trip, it can be said to classified as a low cost. In another case, if the nominal only counted for just one trip, it can say that these costs classified as expensive. The same case is also applicable for people who pay the travel cost around IDR 10.000 to IDR 20.000 and IDR 30.000 to IDR 40.000 .

Table 8. Travel cost of people in transit point of Lebak Bulus

\begin{tabular}{|c|c|c|}
\hline No & Cost Estimation & Percentage (\%) \\
\hline 1 & >IDR 10.000 & 6 \\
\hline 2 & IDR 10.000 - IDR 20.000 & 53 \\
\hline 3 & IDR 20.000 - IDR 30.000 & 37 \\
\hline 4 & IDR 30.000 - IDR 40.000 & 4 \\
\hline
\end{tabular}

Similar things also occur for people who travel and transit in the TOD of Lebak Bulus. According to the survey, the travel cost spent by people to travel and transit in the TOD of Lebak Bulus is between IDR 6.000 and IDR 40.000. Based on Table 8, the most dominant travel cost spent by people to travel and transit in the TOD of Lebak Bulus is around IDR

10.000 to IDR 20.000. It classified to be an inexpensive cost for a one-time trip and one round-trip. For people who have the travel cost around IDR 30.000 to IDR 40.000, it can say to be a similar case with people who travel and transit in the TOD of Dukuh Atas.

Besides the travel cost, economic activity also identified based on the economic planning around the TOD area lead by the management of the transportation mode. The management cooperating with several franchises, restaurant, market, and drug store, to open their retail in several MRT stations, especially in the Dukuh Atas and Lebak Bulus Station. The retails expected to raise the economic activity and give the economic benefit for people who travel and transit around the TOD area. The retails that available at the Dukuh Atas and Lebak Bulus station are Alfa Express, Starbuck Coffee, Kafe Betawi, Indomaret, Century, Family Mart, Shilin Taiwan Street Snacks, Lawson Stations and many more. One example of the retails in the TOD area showed in Fig. 4.

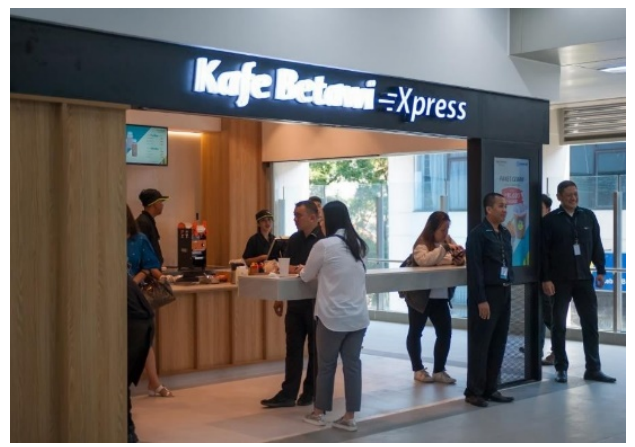

Fig. 4. Retail store in transit point 


\subsection{Life Quality}

The last variable in terms of socio-economic behind the TOD of Jakarta is life quality. The life quality described based on three aspects as economic benefits, social benefits, and environmental benefits. In advance of discussing it further, there is a crucial thing to discuss, namely the people's knowledge of TOD itself. It relates to how the objectives of providing TOD facilities can be conveyed and provide benefits to the community. It based on the reality that TOD is a new concept of urban development and still being an unpopular urban phenomenon in this country.

Table 9. Knowledge about TOD

\begin{tabular}{|c|c|c|c|c|}
\hline \multirow{2}{*}{ No } & \multirow{2}{*}{ TOD Area } & \multicolumn{3}{|c|}{ Responses (\%) } \\
\cline { 3 - 5 } & & Not Know & Know & Just/Ever Heard \\
\hline 1 & Dukuh Atas & 74 & 21 & 5 \\
\hline 2 & Lebak Bulus & 79 & 16 & 5 \\
\hline
\end{tabular}

According to the survey, the majority of people who travel and transit in both the TOD area, Dukuh Atas and Lebak Bulus, still do not know about what the TOD concept is. It proves that the TOD concept still unpopular among the urban community in Indonesia. Table 9 shows the percentage of people knowing about the TOD concept. There are only $20 \%$ of people who already know about this concept. It can influences the way of community perceives the benefits of TOD.

Economic benefits are the first aspect to discuss in terms of life quality. According to the survey, there are three kinds of responses from people in the TOD area when asked about economic benefits. The majority of people traveling and transiting in the TOD area can take economic benefits that are cheap travel costs. On the other hand, several people yet to take economic benefits due to their assumption that the travel cost still expensive. They also assume that there is no alteration before or after using public transportation and transiting in the TOD area. These things occur due to the different origin and destination of each transit people. The percentage of responses from people traveling and transiting in the TOD area showed in Table 10.

Table 10. Economic benefits of TOD area

\begin{tabular}{|c|c|c|c|c|c|}
\hline \multirow{2}{*}{ No } & \multirow{2}{*}{ TOD Area } & \multicolumn{4}{|c|}{ Responses (\%) } \\
\cline { 3 - 6 } & & Cheap & Expensive & The Same & The Rest \\
\hline 1 & Dukuh Atas & 69 & 15 & 16 & 0 \\
\hline 2 & Lebak Bulus & 41 & 31 & 27 & 1 \\
\hline
\end{tabular}

The further aspect to discuss in terms of life quality is social benefits. According to the survey, there are three kinds of responses related to this benefit from people traveling and transiting in the TOD area. The majority of people traveling and transiting in the TOD area yet to take any social benefit. It proves that people around the TOD area show an individuality behavior and not interested in interacting with other people using the TOD facilities. On the other side, people already take the social benefits of the TOD area. The percentage of responses from people traveling and transiting in the TOD area showed in Table 11.

Table 11. Social benefits of TOD area

\begin{tabular}{|c|c|c|c|c|c|c|}
\hline \multirow{2}{*}{ No } & \multirow{2}{*}{ TOD Area } & \multicolumn{5}{|c|}{ Responses (\%) } \\
\cline { 3 - 7 } & & None & Interaction & Exercise & New Culture & Easy Activity \\
\hline 1 & Dukuh Atas & 37 & 32 & 5 & 10 & 6 \\
\hline 2 & Lebak Bulus & 42 & 36 & 13 & 9 & - \\
\hline
\end{tabular}


The final aspect to discuss in terms of life quality is environmental benefits. According to the survey, there are three kinds of responses related to this benefit from people traveling and transiting in the TOD area. The majority of people around the TOD area regard that their behavior of using traveling with public transportation, and transit in the TOD area contributes to reducing the pollution in the urban area. The minority of them are comfortable to do so due to the proper facilities provided by the management of transportation mode. The percentage of responses from people traveling and transiting in the TOD area showed in Table 12 .

Table 12. Environmental benefits of TOD area

\begin{tabular}{|c|c|c|c|c|}
\hline \multirow{2}{*}{ No } & \multirow{2}{*}{ TOD Area } & \multicolumn{3}{|c|}{ Response (\%) } \\
\cline { 3 - 5 } & & Reduce Pollution & Not Useful Yet & Comfortable \\
\hline 1 & Dukuh Atas & 72 & 10 & 18 \\
\hline 2 & Lebak Bulus & 68 & - & 32 \\
\hline
\end{tabular}

This research reveals that time efficiency is becoming the main driver for the community to use public transportation and transit in the TOD area. This thing related to the research conducted by [15] focusing on the transfer time of the passengers on the transit point of public transportation driving increased interest in the transit community-efficiency of travel time using public transportation caused by short transfer dan travel time. This research also parallels with the research conducted by [16] discussing the efficiency of travel and transfer time of the transit community. The rapid arrival and departure frequency and the short interlude of every mode creating travel time efficiency take by the transit community.

This research also reveals the same thing to what conducted by [16], the economic activity in the TOD area indicated by facilities of the social concentration for the community, namely retail stores in and around the transit center. This research also reveals the increase in life quality of the transit community. The increase of life quality in terms of economic benefits is related to what stated by [17], namely savings in travel costs due to the activity without a private vehicle. In terms of social benefits, this research is related to the statement of [1], namely the emergence of interaction and physical activity around the people travel and transit in the TOD area. In terms of environmental benefits, this research is related to the statement of [8], namely the decrease in the number of traffic jams and air pollution.

On the other hand, this research is contradictive with the research conducted by [18]. That research discovers that the economic benefits in public transportation are not low costs, but it shows the high costs. The research also discovers the possibility of urban sprawl dan increasing the long-distance travel due to the ability of the community outside the urban area to pay the travel costs. The contradictive emerge between this research and the research conducted by [18] is due to the cheap travel costs being the economic benefit gathered by the transit community using public transportations.

\section{Conclusion}

The TOD area in Jakarta shows socio-economic aspects seen from several factors, such as mobility movement, economic activity, and life quality. The mobility movement in both TOD shows a stable condition. It indicated by the average passenger movement reaching 140.168 passengers a month. Its movement caused by the time efficiency of the travel and transfer time. The economic activity in the TOD caused by the movement of people around the area. This activity occurs throughout the working day or five days a week. On the other side, the TOD area equipped by retail stores that serve as a facility for economic activity and the addition of passenger travel value. The TOD areas are also creating the life quality change of people who travel and transit on the transit point. It proved by economic benefits, social 
benefits, and environmental benefits. People who travel and transit around the TOD area have gotten the economic benefits and environmental benefits, while the social benefits still not yet felt so effective.

\section{References}

[1] M. Kamruzzaman, D. Baker, S. Washington, and G. Turrell, "Advance transit oriented development typology: Case study in brisbane, australia," J. Transp. Geogr., vol. 34, pp. 54-70, (2014).

[2] J. Guo, F. Nakamura, Q. Li, and Y. Zhou, "Efficiency Assessment of Transit- Oriented Development by Data Envelopment Analysis: Case Study on the Den-en Toshi Line in Japan," J. Adv. Transp., vol. 2018, (2018).

[3] D. Pojani and D. Stead, "Dutch planning policy: The resurgence of TOD," Land use policy, vol. 41, pp. 357-367, (2014).

[4] R. Huang, A. Grigolon, M. Madureira, and M. Brussel, "Measuring transit-oriented development (TOD) network complementarity based on tod node typology," $J$. Transp. Land Use, vol. 11, no. 1, pp. 304-324, (2018).

[5] W. M. Wey, H. Zhang, and Y. J. Chang, "Alternative transit-oriented development evaluation in sustainable built environment planning," Habitat Int., vol. 55, pp. 109123, (2016).

[6] K. Credit, "Transit-oriented economic development: The impact of light rail on new business starts in the Phoenix, AZ Region, USA," Urban Stud., vol. 55, no. 13, pp. 2838-2862, (2018).

[7] P. Phani Kumar, C. Ravi Sekhar, and M. Parida, "Residential dissonance in TOD neighborhoods," J. Transp. Geogr., vol. 72, no. September, pp. 166-177, (2018).

[8] A. Nasri and L. Zhang, "The analysis of transit-oriented development (TOD) in Washington, D.C. and Baltimore metropolitan areas," Transp. Policy, vol. 32, pp. 172-179, (2014).

[9] Q. Shen, S. Xu, and J. Lin, "Effects of bus transit-oriented development (BTOD) on single-family property value in Seattle metropolitan area," Urban Stud., vol. 55, no. 13, pp. 2960-2979, (2018).

[10] D. van Lierop, K. Maat, and A. El-Geneidy, "Talking TOD: learning about transitoriented development in the United States, Canada, and the Netherlands," J. Urban., vol. 10, no. 1, pp. 49-62, 2017.

[11] K. C. Strong, M. E. Ozbek, A. Sharma, and D. Akalp, "Decision support framework for transit-oriented development projects," Transp. Res. Rec., vol. 2671, no. Mcdm, pp. 51-58, (2017).

[12] C. D. Higgins and P. S. Kanaroglou, "A latent class method for classifying and evaluating the performance of station area transit-oriented development in the Toronto region," J. Transp. Geogr., vol. 52, pp. 61-72, (2016).

[13] A. Ibraeva, G. H. de A. Correia, C. Silva, and A. P. Antunes, "Transit-oriented development: A review of research achievements and challenges," Transp. Res. Part A Policy Pract., vol. 132, no. October 2019, pp. 110-130, (2020).

[14] R. B. Noland, M. D. Weiner, S. DiPetrillo, and A. I. Kay, "Attitudes towards transitoriented development: Resident experiences and professional perspectives," J. Transp. Geogr., vol. 60, pp. 130-140, (2017).

[15] L. Groenendijk, J. Rezaei, and G. Correia, "Incorporating the travellers' experience value in assessing the quality of transit nodes: A Rotterdam case study," Case Stud. Transp. Policy, vol. 6, no. 4, pp. 564-576, (2018).

[16] G. J. Peek and M. Van Hagen, "Creating synergy in and around stations: Three strategies for adding value," Transp. Res. Rec., no. 1793, pp. 1-6, (2002). 
[17] C. Curtis, J. L. Renne, and L. Bertolini, Transit oriented development: Making it Happen. (2009).

[18] J. De Vos and F. Witlox, "Transportation policy as spatial planning tool; Reducing urban sprawl by increasing travel costs and clustering infrastructure and public transportation," J. Transp. Geogr., vol. 33, pp. 117-125, (2013). 